Vesna Krajišnik*

Faculty of Philology

University of Belgrade

Nikica Strižak

Faculty of Philology

University of Belgrade

Dušanka Zvekić Dušanović

Faculty of Philology

University of Novi Sad
DOI https://doi.org/10.18485/fid.2019.9.ch6

UDC 376.7-054.57:811.163.41

\title{
IMPROVING THE TEACHING OF SERBIAN \\ AS A NON-MOTHER TONGUE IN PRIMARY EDUCATION \\ OF ALBANIAN NATIONAL MINORITY IN SOUTHERN SERBIA
}

\section{Summary}

The analysis of the results of the Serbian language assessment among primary school pupils in the municipalities of Preševo, Bujanovac and Medveđa conducted in 2014 as part of the Study drafted by the Government of Serbia Coordination Body for the Municipalities of Preševo, Bujanovac and Medveđa with the support of the Ministry of Education, Science and Technological Development of the Republic of Serbia proved that only a small number of pupils in Albanian language schools possesses functional knowledge of the Serbian language. Seeking to remedy this problem, a set of recommendations was proposed to improve the teaching and learning of Serbian as a non-native tongue.

This paper aims to analyse the effects of the implementation of two recommendations that focus primarily on the teaching process - teacher training and periodic assessment of pupils' progress in the acquisition of the Serbian language. We also aim to point to the ways of customizing the Curriculum to the actual requirements of the teaching process in accordance with the real competences of the pupils, the selection of grammatical and lexical content and the most appropriate methodological strategies for achieving the estimated goals and standards.

Key words: Serbian as a non-mother language, glottodidactics, educational standards, learning outcomes.

*_krajisnikv@gmail.com, snikica@gmail.com,dusazd@gmail.com 


\section{Introduction}

Following years of neglect when it comes to the importance of learning the Serbian language that consequently led to a form of linguistic self-isolation in the municipalities of Preševo, Bujanovac and Medveđa, inhabited by the Albanian national minority, the Government of Serbia's Coordination Body instigated a series of activities in order to outline the existing circumstances regarding Serbian as a non-mothertongue and define the appropriate systematic solution.

The initial step was to instigate the Study on the Possibilities for Improving the Teaching and Learning of Serbian as a Non-Mother Tongue in the Municipalities of Preševo, Bujanovac and Medveđa (hereinafter: the Study), which would provide a clear and well-substantiated report of the linguistic, and more broadly, socio-cultural circumstances in the three municipalities and an expert analysis and recommendations for the improvement and a long-term solution for the problem.

The Government of Serbia Coordination Body began the aforementioned Study in 2013, the realization of which was supported by the Embassy of the United Kingdom and the office of the OSCE's High Commissioner for National Minorities. The research for the Study was also supported by The Ministry of Education, Science and Technological Development of the Republic of Serbia. Experts from the University of Belgrade and Novi Sad were involved in the analysis of the statistical data of the linguistic content.

\section{Current situation in teaching Serbian as a non-mothertongue}

The framework of the research was determined according to the international standards and the current laws and regulations of The Republic of Serbia regulating the rights of the national minorities in the domain of mother language education. The methodology of the research included:

The initial assessment of fourth and eighth grade pupils in 16 Albanian language schools. In order to determine the language levels, it has been decided to include pupils who have completed the first and second cycle of primary education; 
- Observation of the teaching process of Serbian as a non-mothertongue with the aim of producing valid conclusions about the implementation of linguistic, methodological and pedagogical approaches on the part of the teacher, pupils' attitudes to the subject as well as the overall atmosphere in the classroom;

- The analysis of the current curriculum for Serbian as a nonmother tongue;

- An elaborate linguistic (grammatical, lexical and cultural) and methodological analysis of the textbooks and reference books used in teaching Serbian as a non-mothertongue as sole glottodidactics tools;

- The analysis of teachers' and pupils' opinions regarding the compatibility and the implementation of the Curriculum, teaching tools, number of hours, aims and pupils' needs, etc. ${ }^{1}$

\section{The initial assessment}

The Serbian language assessment of forth and eighth grade pupils from 16 Albanian language schools was carried out in order to determine the real knowledge of the Serbian language. The functional knowledge within the three language skills was tested: listening, reading and writing (lexical and grammatical competence in guided and independent production). Speaking skills were tested only among pupils who achieved adequate results in the test. The test intended to assess the functional usage of the language (lexis and grammar determined by the current curriculum). In order to ensure the understanding of the task requirements, the instructions were given in both languages, Serbian and Albanian, along with oral instructions in Albanian explaining the procedure of solving the task. Furthermore, an illustration of the solving procedure was provided for each task.

Both pupils and teachers were informed that the obtained data would be used for research purposes only, and not for the assessment of the academic achievement. The estimated time for the completion of the test was 45 minutes.

Based on the results of the test, the following conclusions were reached:

$1 \quad$ For more details see the Study (2014). 
1. Pupils are not familiar with this form of testing as a knowledge assessment tool; regardless of the elaborate instructions for solving the tasks, the pupils were unclear about what was required and would mostly leave blank spaces or copy the model of the task provided in the instruction.

2. Apart from using the Cyrillic alphabet (copying singular words for fourth grade pupils and shorter sentences for eighth grade pupils), pupils mostly failed to demonstrate the required minimum of linguistic competences equivalent to the A1 level of the Common European Framework of Reference for Languages (Council of Europe 2001).

3. 33 pupils out of 433 of those tested (11 from the fourth and 22 from the eighth grade) achieved significantly better results so their speaking competence was assessed; based on the interview conducted with these pupils, it was concluded that their knowledge of Serbian was not the result of the teaching process. ${ }^{2}$

Table 1. Average values for 4th and 8 th grade students.

\begin{tabular}{|l|c|c|}
\hline \multicolumn{3}{|c|}{ Municipalities of Bujanovac and Preševo } \\
\hline Linguistic competences & 4th grade & 8th grade \\
\hline Grammatical literacy & $5.67 \%$ & $9.56 \%$ \\
\hline Lexis & $6.52 \%$ & $2.04 \%$ \\
\hline Independent written production & $4.34 \%$ & $10.76 \%$ \\
\hline Listening comprehension & 2.85 & $6.27 \%$ \\
\hline Reading comprehension & 2.78 & $2.94 \%$ \\
\hline
\end{tabular}

\section{Implementation of the curriculum}

Monitoring in the process of determining the current state of affairs regarding the teaching of Serbian as a non-mother tongue involved the presence of the researchers in the classroom and the observation of the process of Curriculum implementation. Numerous shortcomings became evident when compared to the current methodological approaches: (1) teachers would closely follow the content and the dynamics of the curriculum regardless of the pupils' achievements and the tempo of the pre-

2 Complete data on the achieved scores in the assessment for each school, in each of the skills can be seen in the Study (2014: 123-150) 
sentation and the manner of revising the content was not compatible with the achieved linguistic competences of the pupils and yielded no results; (2) communication was one-sided, the teacher had a dominant role in the classroom with hardly any interaction with the students apart from those who could already speak Serbian; (3) considering the absence of any form of communication, the translation method was used both in teaching grammar and explaining the vocabulary; (4) pupils' productive skills extended solely to converting the text from Latin into Cyrillic alphabet and reading; both activities implied no understanding of the content.

\section{The Curriculum}

The curriculum is one of the key factors in the teaching process. It is vital, therefore, to consider its appropriateness for teaching Serbian as a non-mother tongue.

The fact that there is one curriculum for teaching Serbian as a nonmother tongue irrespective of the pupils' mother tongue raises a question about whether it is possible to have a uniform curriculum adequate for all students learning Serbian.

The analysis of the curriculum ${ }^{3}$ indicated that significant differences in the level of the pre-existing knowledge of Serbian and the rate at which it is possible to acquire the language during education are not reflected in the projected goals and the content of the existing curriculum. The existing curriculum does differentiate between the elementary and expended goals. However, the differentiation seems minimal and reduced to the number of words that need to be learned along with certain grammatical items in the Language section.

A careful analysis of the curriculum for this school subject indicates that it is partly based on the principles of the second language acquisition, which is most obviously evident in the Language Content section. Here, the language units are represented as minimal units that are gradually introduced, becoming more elaborate and complex in higher grades and which require practice to ensure their independent usage in the appropriate communicative context. On the other hand, certain elements of the curriculum are equivalent to the curriculum for the Serbian language and literature (Serbian

3 A more comprehensive overview of the Curriculum for Serbian as a non-mother tongue is available in Zvekić-Dušanović (2016: 671-675) and the Study (2014: 49-66). 
as a mother tongue) specifically in the section dedicated to the reading material, i.e. a list of set-books. The list mainly includes works of literature originally written in Serbian, the introduction of which is planned for the $5^{\text {th }}$ grade. These works undoubtedly fulfil the educational and aesthetic criteria and are mostly appropriate for the students of that age. However, almost all of them exceed the lexical and grammatical minimum planned for this subject. This is especially noticeable in the works from oral literature which are rich in archaic words, mostly non-existent in current standard of the Serbian language. ${ }^{4}$

The content of the curriculum does determine the rate of acquisition of the Serbian language; however, it is suggested in the instructions for its implementation that new material should not be introduced until the old one has been mastered. In reality, there is a tendency to follow the pace determined by the curriculum despite the fact that the old material has not been learned. Such material accumulates and the Serbian language lessons become a formality, i.e. pretence that the curriculum has been properly implemented. As a rule, the teachers are not willing to diverge from what has been determined by the curriculum, i.e. what has been included in the textbook. ${ }^{5}$

\section{Textbooks}

The textbooks for Serbian as a non-mother tongue, as well as the curriculum for the subject are uniform for all the students who learn Serbian. ${ }^{6}$ They should cater to the needs and abilities of pupils with different levels of linguistic competence in Serbian. Since they include both elementary and expended elements of the curriculum, the textbooks are

$4 \quad$ It needs to be highlighted that major changes in the Curriculum are made during 2017 and early 2018 and that new Curriculum should enter schools in September 2018. The new curriculum takes into account two factors addressed in this paper: linguistic differences between mother tongue and Serbian, as well as amount of contact with Serbian language outside of the classroom. New textbooks are also being written. Further research will show the effects of the new Curriculum and new textbooks.

5 The interviews with the teachers revealed that, before the training program began, a large number of them had no insight into the Curriculum. The Curriculum was identified with the operational plans that were usually inherited from colleagues and were used in teaching without any adjustments.

6 For detailed information on textbooks, see Zvekić-Dušanović (2011: 154-161) and the Study (2014: 97-122). 
comprehensive and require significant skills on the part of the teacher to select the material appropriate for the pupils' abilities. Although the elements that belong to the expended curriculum are marked in the textbooks, even those that are deemed elementary surpass the level of pupils with a weaker command of the language. For the pupils whose mother tongue is a non-Slavic language, it is necessary that teachers make a selection of materials, adapt them and create additional teaching material.

\section{Recommendations for Improving the Teaching of Serbian as a Non-Mother Tongue}

Based on the elaborate analysis of the teaching practice in Serbian as a non-mother tongue in primary schools in the municipalities of Preševo, Bujanovac and Medveđa, the team of experts involved in the realization of the Study proposed recommendations for the improvement of the teaching of Serbian as a non-mother tongue based on linguistic, methodological, pedagogical, and socio-cultural aspects. Considering the timeframe for their realization, they are classified as short-, medium- and long-term goals. In this paper we aim to present those that are classified as short-term recommendations because all of them have already been implemented and started bringing significant results in teaching Serbian. It would certainly be useful to follow the implementation of medium- and long-term recommendations and present them in future research.

\section{Teacher training}

The Study established that most teachers involved in teaching Serbian as a non-mother tongue in these municipalities do not have the required competences, i.e. lack adequate professional skills for teaching this subject. Significant number of teachers did not graduate from the departments of Serbian language, none of them had any prior training in teaching a second language, and for one part of them Serbian is not a mother tongue. Considering the teachers' importance in the organization of the teaching process and the outcome of the same process, one of the recommendations is to organize training sessions which would focus on the key topics of the methodology of teaching a non-mother tongue. 
The basic goals of the training entail familiarizing the teachers with the current concepts in teaching and learning a non-mother tongue/second language, mastering the basic theoretical concepts in this field, and ensuring their practical application. In accordance with these goals, the training includes topics that enable the participants to acquire knowledge on current trends in the methodology of second language teaching. The teachers also discuss these topics and are encouraged to provide information about their own teaching practices and ideas about new possibilities in accordance with the actual conditions regarding the realization of the teaching process.

\section{Hiring Teaching Assistants}

One of the recommendations suggested hiring assistants to the teachers who are main agents in the teaching process in selected schools. The main criteria in the selection of candidates were: a Bachelor degree in Serbian language studies, an aptitude for using innovative and current methodological approaches in the teaching process and the willingness to live in the area of their employment. Six candidates were selected in the public competition and were introduced to the teaching process at the beginning of the school year of 2015/2016. The selected assistants were involved in the training programs along with the teachers and began implementing the newly acquired methodological principles in the classroom.

The involvement of teaching assistants brought about the individualization of the teaching process, i.e. the assistants were able to detect individual problems in the teaching process and, by approaching them in a creative and professional manner, enable the progress of every pupil. Likewise, the pupils, motivated by their progress in acquiring language competences in a less formal atmosphere of the classroom, found it easier to master the subject matter, thus fostering curiosity for the new language content.

\section{Continual Assessment}

One recommendation that was implemented along with hiring teaching assistants is the continual assessment of pupils in classes with teaching assistants. The fourth and the seventh grade pupils from four primary schools 
in Preševo and Bujanovac were involved. The aim of these assessments was to provide constant feedback regarding the progress of both teachers and pupils in order to ensure continual progress. An equally important argument in favour of continual assessments is the opportunity to measure the success of the whole project whose main goal was to improve the knowledge of the Serbian language. The data obtained through assessments were expected to indicate a progress in pupils' knowledge as well as in the application of the new methodological principles in teaching and to point to possible problems and challenges that teachers face. The data based on the assessment results could provide new ideas about improving the teaching process.

Following primary schools were involved in the continual assessment:

1. Ibrahim Keljmendi Primary School (IK in the chart), Preševo - six classes of the fourth grade and six classes of the seventh grade;

2. Muharem Kadriu Primary School (MK in the chart), Veliki Trnovac (municipality of Bujanovac) - four classes of the fourth grade and five classes of the seventh grade;

3. Seljami Halači Primary School (SH in the chart), Oraovica (municipality of Preševo) - two classes of the fourth grade and two classes of the seventh grade; and

4. Naim Frašeri Primary School (NF in the chart), Bujanovac - two classes of the fourth grade and two classes of the seventh grade.

The assessment was anonymous and the pupils were informed that the results would not affect their academic achievement, or be entered into school registers. The teachers were also informed of the fact.

The assessment was conducted continually, three times in the course of the academic year:

- The first assessment took place on the $28^{\text {th }}$ and $29^{\text {th }}$ of September 2015 and included 282 fourth grade pupils and 361 seventh grade pupils;

- The second assessment took place on the $25^{\text {th }}$ and $26^{\text {th }}$ of February 2016 and included 293 fourth grade pupils and 360 seventh grade pupils;

- The third assessment took place on the $30^{\text {th }}$ and $31^{\text {st }}$ of May 2016 and included 293 fourth grade pupils and 341 seventh grade pupils. 
The pupils were tested at the premises of their own schools in two sessions. The allocated time for completion was 45 minutes. The assessment was conducted by the members of the project team with the help from the teaching assistants and teachers.

\section{Structure and content of the test}

Both tests were composed of 7 tasks; 45 minutes were allocated for the completion of the test. The maximum number of points for the entire test was 50 .

In their structure the tests resembled the initial tests used for the purpose of the Study in accordance with the Common European Framework of Reference for Languages, A1 level (for grade four), A2 (for grade seven).

The Latin alphabet was used in the tests in order to avoid possible difficulties in case of poor familiarity with the Cyrillic alphabet, the knowledge of which was tested in a separate task. The instructions for the tasks were bilingual (i.e. in Albanian and Serbian) and each task was illustrated by an example of a completed task. The use of grammatical terms was circumvented by providing the appropriate functional language context, which prompted and guided the pupils in their answers.

The task type was adjusted to the type of request, pupils' age, and the dynamics of the test: a) multiple choice (circling the correct answer, matching two concepts), b) filling in the blanks with the correct form of the words, c) converting words or sentences from one alphabet into another, d) sentence transformation following the provided criteria, e) answering questions, and f) describing pictures.

The following competences were assessed by the test:

1. Writing: a) familiarity with both scripts of the Serbian language;

b) autonomy in writing shorter texts - description of a picture;

c) functional grammatical literacy - correct use of grammatical forms of the standard variety in the language context and d) the use of lexis for different topics appropriate for the pupils' age.

2. Reading: reading comprehension;

3. Listening: listening comprehension.

Considering the number of students involved in the assessment it was not possible to conduct interviews with the pupils. 
Analysis of the results

A few general observations can be singled out based on the results of the three assessments:

- Better verbal communication with the pupils was gradually established before and after the assessments. This was not tested or measured, but all testers had the same experience - pupils gradually started producing minimal phrases, either as answers to our questions, or as questions they were interested to ask us.

- The pupils mastered the technique of doing this type of test. This type of knowledge assessment was not initially familiar to the pupils, which affected the outcome of the initial testing, whose results were presented in the Study (2014).

- Continual assessment shortened the time needed for the completion of the test.

Based on the analysis of the results in the three assessments of fourth and seventh grade pupils from September 2015 to June 2016, a significant progress in learning Serbian was observed in all four primary schools; also, in February compared to September and in May compared to February (see Figure 1).

Figure 1. The average number of points (max 50) per school.

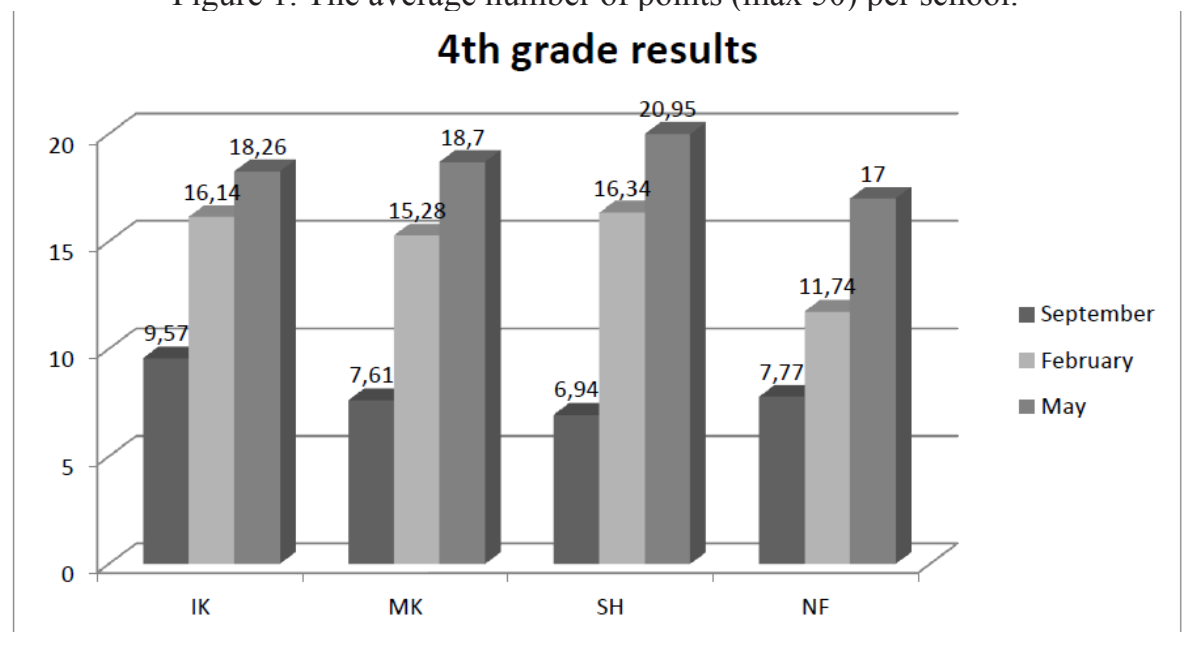


The best results among the fourth grade pupils were achieved in acquiring the vocabulary, which is evident in the written production. The tasks that tested this competence required the adequate usage of grammar and vocabulary. In case of the incorrect lexical or grammatical form, half a point was allocated to the task in question. The argument in favour of this decision is the understanding of the statement (despite the ungrammatical forms) which represents the most significant progress in language acquisition.

Moderate success was achieved in using the Cyrillic alphabet, which is understandable since the acquisition of the script is expected in the fourth grade and the level of automatism has not been achieved yet. Even though knowledge of the alphabet does not indicate the language level itself, and even though Serbian language is written in Latin alphabet as well, we find knowledge of Cyrillic alphabet to be highly important, considering that, by Constitution, ${ }^{7}$ Cyrillic alphabet is the official alphabet of the state of Serbia. This implies that all official documents issued by the state are written in the Cyrillic alphabet. For the future life and employment in the Republic of Serbia, for communication with institutions of the state, knowledge of Cyrillic alphabet is necessary.

Insufficient progress was achieved in listening and reading comprehension, which can be explained by the fact that these skills require longer exposure to the language (both written and spoken).

The poorest results were achieved in grammatical competence, which is understandable considering the long-term absence of any kind of systematic approach to learning of the Serbian language. Individually, students with more systematic knowledge of the language and those who achieved better results in the test displayed some influence of a dialect as a result of contact with native speakers.

$7 \quad$ Article 10 of Serbian Constitution: Serbian language and Cyrillic script shall be in official use in the Republic of Serbia. Official use of other languages and scripts shall be regulated by the Law based on the Constitution. 
Figure 2. The average number of points (max 50) per school.

\section{7 th grade results}

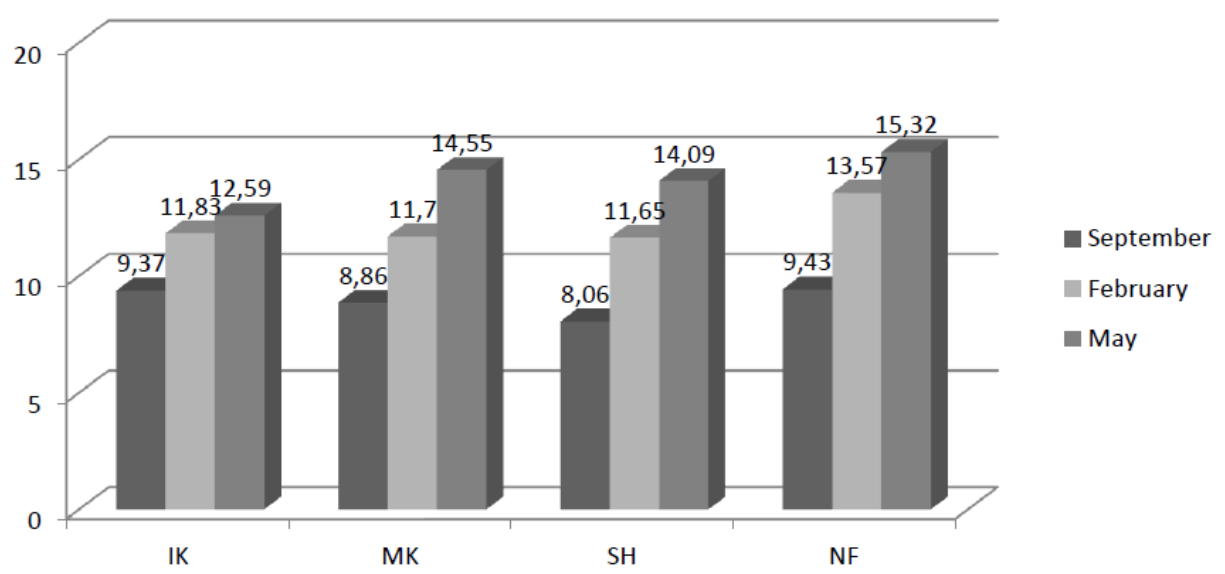

The greatest progress among the seventh grade pupils (see Figure 2) was achieved in writing skills. The autonomous written production (picture description) was significantly improved; the pupils demonstrated the ability to produce a meaningful text with regard to lexis, grammar, and semantics. The results are different to those in September (apart from individual cases) when the results were not positive for the tasks of this type.

The continual assessment proved to be a significant motivator in the learning process and remains a tool to be used in similar situations. The assessments should not be conducted too frequently so as not to disturb the usual dynamics of the teaching process and should include familiar test models. Furthermore, the composition of the test should include all three language skills that can be assessed through tests (reading, writing and listening), since the progress in language learning must be reflected through progress in all of the skills rather than just one.

\section{Standards}

The project Development of Educational Standards for Serbian as a Non- Mother Tongue at the End of First, Second and Third Education Cycle and Adult Primary Education began in early 2015. The Project was managed by the Institute for the Education Quality Assessment with the organiza- 
tional and financial support by the OSCE's Mission in Serbia. The expert committee that included university and school teachers as well as counsellors from the Institute for the Education Quality Assessment and the Institute for the Improvement of Education was formed. Considering the importance of the bill on Common Standards for the entire education system in Serbia, a significant contribution was provided by the representatives of the National Council of National Minorities during the preliminary research for the Project in December 2014 and during the public debate on the Bill on Common Standards (May/June 2016) in the final stage of the Project.

The definition of the education standards was based on legal documents and other strategic documents on education, the existing plans and programs for Serbian as a non-mother tongue, the Institute's experience in developing education standards as well as the experience of the individual members of the committee from their teaching practice. The final text of the document incorporated the following: the analyses of legal documents and professional literature; conclusions based on discussions with teachers of Serbian as a non-mother tongue from different school boards and the representatives of the National Councils of National Minorities; the experiences of members of the committee based on their study trips to the North and South of the Republic of Serbia-visits to schools where Serbian is taught as a non-mother tongue; the results of the assessments for students who study Serbian as a non-mother tongue. ${ }^{8}$

In the document the Educational Standards for Serbian as a NonMother Tongue at the End of First, Second and Third Education Cycle and Adult Primary Education ${ }^{9}$, the standards for the three levels of achieve-

8 The sample included the entire population of eighth grade pupils in primary schools and the final year students of high and vocational schools learning Serbian as a non-mother tongue. Separate tasks were designed for the process of defining the education standards of achievement. The empirical testing of the concept of standards included 104 primary and 43 secondary schools - 2,634 eighth grade pupils from primary schools and 2,165 students at the end of their secondary education. The students' mother tongues included: Albanian, Bulgarian, Croatian, Hungarian, Rumanian, Rusyn, and Slovakian (half of the pupils tested had Hungarian as their mother tongue and one third spoke Albanian as a mother tongue).

9 Only available in Serbian: Krajišnik, Vesna, Dušanka Zvekić-Dušanović. 2017. Opšti standardi postignuća za predmet Srpski kao nematernji jezik za kraj prvog $i$ drugog ciklusa obaveznog obrazovanja, opšteg srednjeg obrazovanja i osnovnog obrazovanja odraslih. Belgrade: OESC Mission in Serbia 
ment were formulated as: elementary, intermediate and advanced, in order to enable students without the previous knowledge of Serbian to achieve a certain level of linguistic competence needed for further education. The linguistic differences between Serbian and the pupils' mother tongue, the linguistic background and the pupils' immediate surroundings, as well as pupils' individual characteristics were taken into consideration in the process of defining the three levels of achievement.

The activities to follow are: familiarizing teachers with the Educational Standards, designing new curricula for Serbian as a non-mother tongue and subsequently, elaboration of new textbooks. The realisation of some of these activities is already in progress. To promote the concept of the Standards and ensure their implementation in the teaching process, a Teacher's Manual has been compiled. The Manual elaborates on the meaning of the term linguistic competence, standards and the three levels of achievement; explains the standards through three modules: Language, Literature and Linguistic Culture; provides task samples for testing the achievement of standards; emphasizes the benefits of learning towards achieving the standards in practice, in day-to-day teaching as well as at the end of education cycles. The preparation of the proposal of the new curriculum for this subject has also been initiated.

\section{Conclusion}

Serbian as a non-mother tongue has been a sensitive issue in the multinational and multilingual environment of the Republic of Serbia, the one that exceeds the boundaries of the linguistic, methodological, and pedagogical interests. It is for this reason that this subject requires a complex, elaborate and sensitive approach in the education system that would lead to a systematic solution which can guarantee results - enable communication in Serbian among all citizens of the Republic of Serbia, i.e. the level of knowledge of Serbian which would enable all members of the national minorities to take part in daily activities and benefit from education and employment opportunities without any restrictions.

Elaborate analyses have led to the conclusion that primary school pupils whose mother tongue is Albanian have very poor knowledge of the 
Serbian language and the reason, for the most part, is the linguistic homogeneity in this part of the country combined with significant linguistic distance, i.e. dissimilarity between the Albanian and Serbian language. $\mathrm{Pu}-$ pils who are raised and educated in linguistically homogenous surroundings are denied a spontaneous contact with the Serbian language native speakers. Schools (with problems related to unqualified teaching staff, and inadequate textbooks and curriculum) are, therefore, the sole providers of opportunities for learning the language. On the other hand, the linguistic distance of the two languages makes the learning more difficult since there is no transfer of the lexical and grammatical content unless explicit instructions are provided. Two languages typologically differ and do not belong to the same language group (although they belong to the Indo-European language family, Serbian is a South Slavic language, whereas Albanian is the sole representative in the Albanian group). These two aspects proved to be crucial in the process of learning a non-mother tongue which is substantiated by the research conducted in Serbia regarding the Albanian and Hungarian language.

A number of activities to achieve the desired level of knowledge of Serbian have been agreed upon in order to create sustainable conditions. These activities imply changes in the methodological approach to teaching (training the teaching staff in accordance with the principles of glottodidactics; adapting the existing materials to the needs and abilities of the pupils; introducing teaching assistants into the teaching process) and constant monitoring of the pupils' achievements (periodic testing during the school year). The implementation of these activities in the selected schools has brought about significant progress in the knowledge of Serbian. However, to ensure a systematic and permanent solution to this problem, it is necessary to implement new Standards which determine the levels of pupils' achievements taking into account the linguistic (dissimilarity between languages) and demographic facts (linguistically homogenous environment), and create new programs and textbooks. Furthermore, the continual training of the teaching staff is crucial since the methodology and course content of Serbian as a non-mother tongue are significantly different to the methodology and course content of Serbian as a mother tongue. 


\section{References}

Bošković, Nataša, Danijela Nenadić, Milica Rodić, Jelena Marjanović, Marija Stanković, Dušanka Zvekić-Dušanović, Vesna Krajišnik, Nikica Strižak, Milan Ajdžanović, and Rahim Salihi. 2014. Studija o mogućnostima unapređenja i nastave Srpskog kao nematernjeg jezika u opštinama Preševo, Bujanovac i Medveđa. [The Study on the Possibilities for Improving the Teaching and Learning of Serbian as a Non-Mother Tongue in the Municipalities of Preševo, Bujanovac and Medveda.] Belgrade: The Government of Serbia Coordination Body for the Municipalities of Preševo, Bujanovac and Medveđa.

Council of Europe. 2001. Common European Framework of Reference for Languages: Learning, Teaching, Assessment. Cambridge, UK: Press Syndicate of the University of Cambridge.

Constitution of Republic of Serbia, available in English at: https:/www.ilo. org/dyn/natlex/docs/ELECTRONIC/74694/119555/F838981147/ SRB74694\%20Eng.pdf (visited on May 10, 2018)

Krajišnik, Vesna, Dušanka Zvekić-Dušanović. 2017. Opšti standardi postignuća za predmet Srpski kao nematernji jezik za kraj prvog i drugog ciklusa obaveznog obrazovanja, opšteg srednjeg obrazovanja $i$ osnovnog obrazovanja odraslih. [The Educational Standards for Serbian as a Non-Mother Tongue at the End of First, Second and Third Education Cycle and Adult Primary Education] Belgrade: OESC Mission in Serbia

Zvekić-Dušanović,Dušanka. 2016. "Neka pitanja nastave srpskog kao nematernjeg jezika u homogenim mađarskim i albanskim sredinama $\mathrm{u}$ Republici Srbiji” In Teme jezikoslovne u srbistici kroz dijahroniju $i$ sinhroniju, zbornik u čast Ljiljane Subotić, edited by Jasmina Dražić, Isidora Bjelaković and Dejan Sredojević, 667-686. Novi Sad: Faculty of Philosophy.

Zvekić-Dušanović, Dušanka. 2011.”Udžbenici za srpski kao nematernji jezik u osnovnoj školi." In Srpski kao strain jezik u teoriji i praksi: tematski zbornik radova, edited by Vesna Krajišnik, 153-162. Belgrade: The Faculty of Philology, The Center for Serbian as a Foreign Language. 


\title{
Vesna Krajišnik Nikica Strižak \\ Dušanka Zvekić Dušanović
}

\section{UNAPREĐIVANJE NASTAVE SRPSKOG KAO NEMATERNJEG JEZIKA U OSNOVNOM OBRAZOVANJU ALBANSKE NACIONALNE MANJINE NA JUGU SRBIJE}

\begin{abstract}
Sažetak
Analizom rezultata provere znanja srpskog jezika kod učenika osnovnih škola u opštinama Preševo, Bujanovac i Medveđa urađenom u okviru istraživanja koje su 2014. godine sproveli Služba Koordinacionog tela Vlade Republike Srbije za opštine Preševo, Bujanovac i Medveđa i Ministarstvo prosvete, nauke i tehnološkog razvoja RS, utvrđeno je da vrlo mali broj đaka koji nastavu prate na albanskom jeziku vlada funkcionalnim znanjem srpskog jezika. U cilju prevazilaženja tog problema predložen je set preporuka za unapređivanje nastave i učenja srpskog kao nematernjeg jezika.

U ovom radu su analizirani efekti realizovanja dveju preporuka koje su najviše usmerene na nastavni proces - obuke nastavnika i periodično testiranje učenika u cilju praćenja napretka u usvajanju srpskog jezika. Ukazuje se na način prilagođavanja Nastavnog plana i programa konkretnim potrebama nastave u skladu sa realnim jezičkim kompetencijama učenika, izbor gramatičkog i leksičkog sadržaja i najpodesnije metodičke postupke za ostvarivanje predviđenih ishoda i dostizanje standarda.
\end{abstract}

Ključne reči: srpski kao nematernji jezik, glotodidaktika, ishodi i standardi. 